\title{
A NEW COMBINATION AND A NEW SYNONYMY IN DISCOCEPHALINI (HETEROPTERA, PENTATOMIDAE)
}

\author{
Miriam Becker ${ }^{1}$ \\ Jocélia Grazia ${ }^{1}$
}

\begin{abstract}
Cataulax varicornis (Walker, 1867) is transferred to the genus Ablaptus Stål, 1864. Ablaptus lopesi Becker \& Grazia, 1989 is considered as a new synonym. The female genitalia is described and illustrated.

KEY WORDS. Pentatomidae, Discocephalini, Cataulax, Ablaptus, new combination, new synonym
\end{abstract}

In the course of the revision of the genus Cataulax Spinola, 1837 (BECKER $\&$ GRAZIA in press) the authors had the opportunity to examine the type specimens of Pentatoma varicornis Walker, 1867, and Cataulax decoloratus Walker, 1868, a female and a male respectively. DISTANT (1899) was the first to recognize the identity of these specimens establishing the synonym between $P$. varicornis and $C$. decoloratus. RUCKES (manuscript) considered them congeneric with Ablaptus Stal, 1864 , so that the specimens were labeled by him as $A$. varicornis.

This new combination is here officially proposed as well as $A$. lopesi Becker \& Grazia, 1989, so far known from a single male specimen (BECKER \& GRAZIA 1989 ) included as a new synonym. The pygophore in the type specimen is lacking, but the shape of the median process of the posterior margin of the seventh segment suffices to characterise this species. The measurements of the female are given and the genitalia described and illustrated

\section{Ablaptus varicornis (Walker, 1867), comb.n.}

Pentatoma varicornis Walker, 1867: 291.

Cataulax decoloratus Walker, 1868: 564. -Lethierry \& Severin, 1893: 85.

Cataulax varicornis; Distant, 1899: 422. - Kirkaldy, 1909: 216. Syn.: C. decoloratus.

Ablaptus lopesi Becker \& Grazia, 1989: 64-66. Syn.n.

Types. Pentatoma varicornis Walker, 1867. Holotype female with following labels: Type, Brit. Mus. Type N HEM 664, Pentatoma varicornis, Braz 6257 , Ablaptus varicornis (Walk.) det. H. Ruckes, 1960. Deposited in The Natural History Museum, London.

1) Departamento de Zoologia, Universidade Federal do Rio Grande do Sul. Avenida Paulo Gama, 90046-900 Porto Alegre, Rio Grande do Sul, Brasil. Bolsista do CNPq.

E-mail: jocelia@vortex.ufrgs.br 
Cataulax decoloratus Walker, 1868. Holotype male with following labels: Amazon, Cataulax decoloratus, Type, Ablaptus varicornis (Walker) det. H. Ruckes, 1960, Brit. Mus. Type No HEM 665. Deposited in The Natural History Museum, London.

Ablaptus lopesi Becker \& Grazia, 1989. Holotype male, from Tapuruquara, Rio Negro, Amazonas, Brazil 25-27/XI/1962 (J. Bechyné). Deposited in the Fundação Oswaldo Cruz, Rio de Janeiro, Brazil.

Female. Measurements (in milimeters). Length of head 1.96; anteocular length 1.14; width of head 3.28; width between eyes 1.80; width between ocelli 1.14; length of antennal segments I 0.82 , II 1.55, III 1.31, IV 2.46, V missing; pronotal length 3.28 ; width across humeri 7.70 ; scutelar length 5.41 ; basal width 4.92; total body length 11.80; width across third abdominal segment 7.05 .

Genitalia. Posterior margin of seventh sternite evenly concave on gonocoxites 8, lateral thirds rectilinear. Gonocoxites 8 with parallel sutural borders; posterior margin truncate and very slightly concave on laterotergites 9 . Laterotergites 9 small, evenly rounded in outline, barely surpassing the transverse band that unites the laterotergites 8 , inner margins slightly overlapping (Fig. 1).

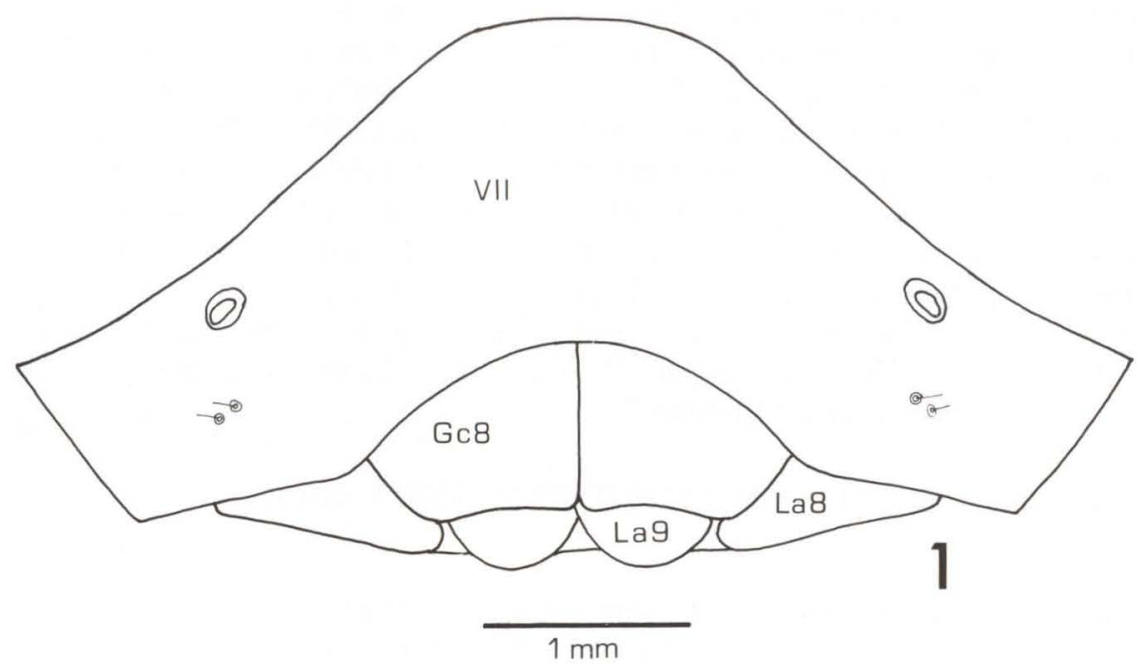

Fig. 1. Ablaptus varicornis (Walker, 1867), holotype, ventral view of the female genital plates. (La8) Laterotergites 8, (La9) laterotergites 9, (Gc8) gonocoxites 8, (VII) seventh sternite.

\section{REFERENCES}

BECKER, M. \& J. GraZIA. 1989. Novas contribuições ao gênero Ablaptus Stal, 1864. (Heteroptera, Pentatomidae, Discocephalinae). Mem. Inst. Oswaldo Cruz 84 (supl. 4): 57-68.

. (in press). Revision of the genera Cataulax Spinola, and Architas Distant 
(Heteroptera, Pentatomidae, Discocephalini). Revta bras. Ent.

Distant, W.L. 1899. Rhynchotal Notes III. Heteroptera: Discocephalinae and Pentatominae (part). Ann. Mag. Nat. Hist. 4 (7): 421-445.

Kirkaldy, G.W. 1909 Catalogue of the Hemiptera (Heteroptera) 1. Cimicidae. Berlim, Felix L. Dames, 392p.

Lethierry, L. \& G. Severin. 1893. Catalogue Général des Hémiptères Pentatomidae. Bruxelles, vol. 1, X+286p.

SPINOLA, M. 1837. Essai sur les genres d'insectes appartenants à l'ordre des Hémiptères, Lin. ou Rhyngotes, Fab. et à la section des Hétéroptères Dufour. Genova, 383p.

STÅL, C. 1864. Hemiptera nonnula nova vel minus cognita. Ann. Soc. ent. France 4: $47-68$.

WALKER, F. 1867. Catalogue of the specimens of heteropterous Hemiptera in the collection of the British Museum. London, British Museum, Part 2, p.241-418.

1868. Catalogue of the specimens of heteropterous Hemiptera in the collection of the British Museum. London, British Museum, Part 3, p.418-599.

Recebido em 07.XI.1996; aceito em 28.V.1997 